\title{
Limits of the Regulatory State Idea: Science and the Cultural Constitution of Capitalist States
}

\author{
Patrick Carroll
}

Department of Sociology, Program in Science and Technology Studies, University of California Davis, USA

\begin{abstract}
This paper is an empirically grounded theoretical critique of the idea of the "regulatory state." The language of the "regulatory state" obscures the nature of the modern state as a constitutive "thing." The modern state is crucially constituted through the co-productions of science and government. It needs to be investigated in terms of its discursive, practiced, and material dimensions, its meanings, its agencies, and its formation as a material entity composed of land, people and built environment. This critique is needed because the idea of the regulatory state too often leaves implicit the notion that capitalism exists prior to the state, and is thus only "regulated" as such post-hoc. The methods used are those of historical sociological case based analytics, utilizing archival materials. The purpose is to challenge the takenfor-granted distinction between the state and capitalist social organization. The implications for further research are the need to delve deeper into the complex entanglements of state and society, and the ironic role that science as culture played in constructing both those concrete entanglements and the abstract bounded categories that obscure them.
\end{abstract}

Keywords: Regulation, technoscience, capitalism, state formation, constitutive view.

The idea of the state as a regulatory apparatus is a common theme in state theory. In this paper I argue that this way thinking about the state has important limitations. I am not suggesting we refrain from the language of "government regulation," but that we become more aware of what that language obscures, in particular the nature of the modern state as a constitutive "thing." I use the term "thing" in the sense that Latour (2004 - engaging with Heidegger) does: as a gathering, a material constitution of humans and nonhumans. I use the term constitutive in the sense given by the Oxford English Dictionary: "Having the power of constituting, establishing, or giving formal, definitive, or organized existence to something." I only add that the state constituted through the co-productions of science and government needs to be investigated in terms of its discursive, practiced, and material dimensions, in terms of its meanings, its agencies, and its formation as a material country of land, people and built environment. Some work that uses the language of regulation does so in a very conventional sense, focused on regulatory agencies or apparatus and the struggles around them, without much thought given to the construction of new meanings of the state over time or new material states of being over time, that is, to processes of state formation. In this context, the language of the regulatory state is assumed to capture all that needs to be said about the state.

The conventional use of the language of the regulatory state articulates well with discourses and

*Address correspondence to this author at the Department of Sociology, UC Davis, One Shields Ave., Davis, CA 95816, USA; Tel: 530-754-0788;

Fax: 530-752-0783; E-mail: pcarroll@ucdavis.edu groups engaged in struggle over regulation, for instance, market fundamentalists versus environmentalists. Those who use the language of the regulatory state in a conventional sense tend not to be conversant with historical sociology of state formation or Science and Technology Studies (STS). Categories such as state, science, nature, the economy, and civil society, are taken to be stable referents to well bounded objects in the world. As Sheila Jasanoff (1995) notes, this view is not supported by research in STS. While the idea of the regulatory state can capture one aspect of the state in the specific moment of the contemporary context, particularly the context of the institutionalization of "regulatory science" and its relations to environmental, labor, and consumer protection movements, the idea of the constitutive state aims at capturing the state both as a process of formation and as a condition which is always unfolding and which is never finished. One might think of the regulatory view as synchronic, and the constitutive as diachronic - granting of course that regulation itself has a history. Much work on regulation is less concerned with the nature of the state, than with struggles over regulation in the context of contemporary science, politics and the policy process. It is organized more around that which is regulated: a particular toxin or carcinogen, the air or water, drugs, food safety, biotechnology, and so forth. The idea of the regulatory state often remains implicit rather than theorized. Discussions of regulation often draw upon Skocpol's (1979) idea of the relative autonomy of the state, for instance, from the interests of capital, but Skocpol's formulation can give the not altogether correct impression (looking at it from the opposite side) that the economy has more autonomy from the state than it 
does. Or more precisely, it fails to capture how free market capitalism is itself constituted within political formations.

The constitutive state idea points to the ongoing constitution of new states of being: political, economic, cultural, and natural. Yet looking to the future this is true only as far as it goes; which is to say that "anything" is not possible. It is not that significant change in regimes of governance and participation etc. are not possible (quite the contrary), but that there are deep historical and cultural logics at work in the modern forms of the capitalist state and of science, and these are sustained by deeply institutionalized practices and material forms, such that new participants are often forced to adapt to them as a price of participation (Kuhn 1962; Epstein 1995). To paraphrase Edmund Burke, the further we penetrate the art of politics the further we find ourselves from the aims that led us to enter it in the first place. I will return to these issues, but now I want to proceed to a discussion of what I see as some of the problems with the idea of the regulatory state, particularly its relationship to its conceptual other, the so-called free market (capitalist) economy. I will follow this with a discussion of the constitutive state, making empirical reference to science and state formation in the cases of Ireland and California.

First, and perhaps most importantly, the discourse of regulation appears inextricably bound up with the discourse of free market economics. The notion of the regulatory state implies that capitalism exists in advance of government action, and only then, post hoc, is it regulated. This idea is mirrored in economics, where economists believe they simply describe rather than make markets. A growing literature in STS is showing this is far from the case, particularly with respect to financial markets, which in important respects are constituted through the work of economists (e.g. Callon, Millo, Muniesa, Eds. 2007; Knorr-Cetina and Preda 2006; MacKenzie 2006). This research is suggestive when it comes to reevaluating the emergence and development of capitalism. The idea of a capitalist economy that emerges according to its own logic may stem historically from the very constitution of the science of political economy, and its relations to government policy. In the early political economy of William Petty, for instance, the nature of the state was to be established through "political anatomy" just as the nature of the body was established by human anatomy. Then, through the application of political arithmetic, its logic and tendencies could be established, i.e., calculated. Government could design policies that comported with economic reality, and grow the economy and the state through the correct political economic policies. Karl Marx's analysis of capital is entirely consistent with this notion of an economy with its own logic. With respect to this economic fundamentalism, the only major difference with classical liberal economists like Adam Smith is that Smith and his latter day adherents believe that the logic of markets will always produce better outcomes than government intervention or "state regulation."

The idea of an economic reality that emerges independent of governance is now coming in for serious question. In historical sociology, for instance, Bruce Carruthers (2005) has shown how industries are importantly constituted through forms of governance, and that markets are importantly constituted in cultural institutions (see also Biernacki 1995). This work is complementing that in STS. And when we go back to the original texts of Smith, it is clear that he viewed laissez-faire not so much as the absence of government, but as a new "police" or policy, a governance that would produce laissez-faire economics (Carroll 2002). Indeed, once we throw off the modernist idea of an economy or of capitalism with a reality and a logic of its own, one governed by universal laws, it becomes obvious that free trade, free markets, and so on, are in important respects the cultural products of policy and state enforcement, that market regimes exist only within particular political and cultural regimes. Capitalism, in effect, is a form "economic culture," a concept even more tricky than that of "political culture," but necessary nonetheless. Perhaps we should stop for a moment talking about the "relationship" between state and economy, and reflect on the idea that there is not capitalism here and the state there, but rather there are capitalist (variably capitalist and non-capitalist) states. That is, we should see that the capitalist polity and the capitalist economy are part of the same system, and that both rest upon the knowledges and techniques that emerged from the new science in the seventeenth century. This would suggest that capitalist economies are not so much regulated by government, as constituted in particular states through the co-productions of science and government. As MacKenzie does with respect to markets (2006), we should investigate how political and economic science not only describes, but projects and performs new reality, bringing capitalism, as we know it into existence. We might see this in a similar way that Bruce Curtis does for population. As Curtis (2002) 
points out, contrary to Foucault's naturalized view of population in which population first exists of itself and only then becomes an object of regulation, population is in fact constituted as a set of relationships and identities through the actions of science and governance. Population is the population of a state. It is not "discovered" by the state, but constituted in the state, a state which itself is reconstituted and reformed in that process. And it is a process that is fundamentally cultural in discursive, practiced, and material form. Population is no more a fiction than it is an object independent of and apart from science and government. It is important in this respect to anatomize "the state" in terms of the state-idea, the state-system, and the state-country. The ideas and discourses of "reason of state" and "political arithmetic" create the abstract concept of population. The agents and agencies of the state-system, in alliance with science, create the documented and classified population as an object of governing practices, and thus as a concrete entity. As Curtis puts it, the "configuration of social relations as population, and the formation of liberal democratic states" are "mutually constitutive" (Curtis 2002:42). In addition, this new entity, the population of a state, reformulates the concrete materiality of the state-country. This new configuration of state idea, system, and country, is in turn central to policies and practices of economic development, and of projects and policies that demarcate the domains of politics and economics.

As the last statement indicates, to say that capitalist economy is constituted in particular political state forms is not to implode the categories of state and economy. Rather it is to say that the very distinctions and boundaries between the domain of government and the domain of capitalist economy are constituted in and through the processes of a specifically capitalist state formation (Mitchell 2002). Thus we can see the state as a constitutive formation, but still speak in the language of regulation. Regulation occurs in the now. Processes of state formation, however, occur over the longe durée. Regulation also has constitutive effects over the longe durée, but it is not the only manner in which the co-productions of science and government constitute the modern state. Indeed, it is secondary to the constitution of the distinct realms of capitalist economics and scientifically informed government, which is the condition of possibility for the regulation of the private by the public.

One way of tracing the cultural and political constitution of capitalism over the longe durée, is by focusing on what in the seventeenth century was called "adventurism" - which has a contemporary echo in the term "venture capitalism," though "venture" was also used in the economic sense as early as 1600 . Adventurism emerges from both within (colonialism) and without (private persons) the state system, though the latter immediately ingratiate themselves within government. The emergence of capitalism is perhaps to be understood as the result of the peculiar intersection of adventurism, government, and science. Such an approach clearly runs counter to the market fundamentalist idea that the economy is an independent reality into which government, post hoc, intervenes to regulate. The underlying theoretical frame for this way of thinking is not, however, confined to right wing ideologues and capitalist economics. It has been at the foundation of dominant historical/political sociology for the past three decades, in the form of what has recently been called a "hyper-structural" political economic analysis (Adams, Clemens, and Orloff. Eds. 2005). The "second wave" of historical sociology tied structural economic determinism to a utilitarian view of human conduct, binding together a Marxian structuralism with a liberal rationalist model of individual conduct. Even when conceding the need to confront the importance of culture, it is still treated as secondary, "as congealed history, as the current residue of collective interaction" (Tilly 1999:411).

New cultural explanations of state formation view culture as a productive force, productive of peculiar economic and political forms, of new knowledges and sciences, new skills and practices, and new material forms. Thus a cultural and constitutive approach would trace the genealogy of the very language of "capital," "capitalist," and "capitalism," these discursively structural pillars of capitalist economics and policy. The first reference to "capital," in the Oxford English Dictionary on Historical Principles (OED 1933), defines it as "relating to the head or top," and is dated as far back as 1225 . This explains the widest contemporary usage of word, from "capital city" to "capital punishment." The first OED reference to capital in economic terms is dated 1709 , and is found, quite tellingly, in an act of government: "An Act for Enlarging the Capital Stock of the Bank of England." The meaning in this context is that of the "original funds," the "head" funds, of a banker, trader, or investor in an $\mathrm{ad} /$ venture. It is surely of interest to cultural analysts that the earliest citation of "capital" in an economic sense (per the OED), is in the context of an act of government. Finally, the first reference to capital in the 
context of distinguishing different forms of economic capital is credited to Adam Smith in 1776, where he distinguishes between fixed and fluid capital. It then becomes a central concept in the emerging classical economics, most famously by Marx in Capital (1974), where he makes a further distinction between variable and constant capital, the former that which is invested in labor-power and which can vary because it can produce surplus value in excess of the capital it consumes, the latter that which is invested in plant and machinery which produces value constant with the capital it consumes - in short, human vs. non-human capital.

The first reference to "capitalist" in the OED is 1798 , defined as one who has accumulated capital understood as money. It is a rather common sense designation of those who, over the eighteen century, became the leading holders of "original," or "investment funds" (fluid capital in Smith's terms). The earliest citation to a "capitalist" is attributed to Arthur Young, who in his travels in France used the word to describe those who collected taxes on bridges and other rights of way; they were "moneyed men" or "capitalists." As with "capital," here again is an unexpected early sense of what a "capitalist" was from a more aristocratic point of view. Capitalists were no blue bloods, and it did not matter where they got their wealth, whether through taxes or investment. Capitalists were simply moneyed men. This is interesting in terms of the cultural construction of capitalist economics, even if it fails to capture the important difference between money and capital, the former given to spending while the latter given to investment. In this context it is worth noting that the first reference to "capitalist," as one who has capital available for employment in financial and industrial enterprises, does not appear (per OED) till 1823. Observe also that it was only in 1888 that Engels, in an English edition of the Communist Manifesto, footnoted "bourgeois" to mean "the class of modern capitalists" (1998:50 note 1). Was this progress in the "discovery" of the objective and independent nature of capitalism, or another moment in the cultural construction of capitalism and our knowledge of it? And what of the etiology of the word "capitalism." In this case the first reference is from 1854, when the word described a "condition of possessing capital." It was used in 1877 to describe the "position" of a capitalist. Only in 1884 was it used to refer to "a system that favors the existence of capitalists." Granted this is only suggestive, but when viewed in the context of the new STS work on the performative and other ways that economists, traders, and state agents construct markets and thereby capitalist economies (MacKenzie 2006; MacKenzie, Muniesa, and Siu, eds. 2007) a genealogy and historicization of some of the foundational categories through which capitalism is understood would likely show how such categories are not merely descriptive of, but constitutive of capitalism.

There are other paths we could follow to investigate the cultural constitution of capitalist economics. For instance, we could look to the history of political economy itself, from Petty to Ricardo, as well as key techniques that are central to accounting, such as double-entry bookkeeping in the construction of scientific facts (Poovey 1998). If wage labor is considered central to capitalism (and most agree it is), then the rise of factory and standardized production are important sites for cultural analysis. For instance, Petty employed and explained his use of division of labor in his survey of Ireland, which involved standardizing techniques and materials across different work groups (Petty c.1659). And Robert Boyle and the other ingenious gentlemen of the Royal Society evoked the charge that their inventions would speed up production, and in effect lead to "deskilling" and unemployment. For instance, Shadwell, in his play The Virtuoso, scripted a Luddite-like scene (a century ahead of the famous King Ludd) that orchestrated both the "enginery" (Carroll 2006) of the new experimental philosophy and the dangers of too close a conversation with it for tradesmen. The scene begins with the virtuoso's house under siege from a "Rabble of People." The virtuoso's servant calls to the crowd across the door to see what they want: "you Son of a Whore" they reply, "the Engine, and the Rogues that invented it." Upon inquiring of the ruckus, the virtuoso is told by his servant "they are Ribbon-weavers; who have been informed, that you are he that invented the Engine-loom, which has provok'd 'em to rise up in Arms." Note that the early nineteenth century Luddites' main grievance was the introduction of wide-framed looms that deskilled textile workers and led to their unemployment. There were genuine grounds for concern. Commenting upon "silk-stockings woven by an engine," Boyle pondered, "what handy work it is, that mechanical contrivances may not enable men to perform by engines?" (Boyle:413).

In addition, while it is conventionally believed that the invention of the steam engine had little to do with science, once the engineering character and the material culture of the new science are factored into the analysis it becomes highly plausible that the steam 
engine would never have been achieved absent the scientific revolution. Many early "engine scientists" like Petty sought to contrive an engine "moved by fire." And Boyle had so much trouble with the valves on his pneumatic engine failing that he badgered London artisans into making him brass valves. Brass valve and vacuum technology, as well as meters of various kinds, were crucial to the steam engine, without which there would have been no deep coal mining, no mass transportation, and no mass production. In short, there would have been no industrial revolution and, therefore, no modern capitalism. If science is to be understood as culture, which is axiomatic in science and technology studies, then here is another avenue for exploring the cultural constitution of our modern economy. Indeed, this line can be pursued further, for it is the very products and effects of science-based production, not to mention the rise of industrial cities, that creates the conditions for the continued growth of a "regulatory" state-system. This is true even though the wider discourses of the new economists of the eighteenth and nineteenth centuries articulated the view that regulation not only hindered efficiency, but also was unnecessary because, as Foucault put it, "there is a spontaneous regulation of the course of things" (2007:344). Foucault claims that because of this new liberal economics "police regulation is pointless," (2007:344) going as far as to say that a "whole new form of governmentality is sketched out that is opposed almost term for term to the governmentality outlined in the idea of a police state," and that "this all really takes place by way of the problem of what is called, or will be called, the economy" (2007:347). On the contrary, however, the police and regulatory apparatus continued to grow, indeed accelerate (Carroll 2002; cf. below), as the co-productions of science and industry continuously unleashed new threats to health, safety, and "the environment" (the concept of "the environment" is anachronistic before the mid-twentieth century). The very sustainability of scientifically informed production spurred the growth of scientifically informed government and police. This STS insight conforms to the findings of the "new economic sociology," which has set out to identify the origins of the "political and economic institutions [cultural] that provide the foundation and scaffolding for modern capitalism" (Nee and Swedberg 2005:xxxvii). Nee and Swedberg continue:

Polanyi's economic sociology highlighted two central pillars of the institutional foundations of modern capitalism, the centralized state - especially its legal and regulatory systems - and the market as an institution of exchange ([1944] 1957). These two institutions are interconnected with all the other key institutions of capitalism, playing a crucial role in determining the structure of property rights, the quality of financial institutions banks and capital markets, and the incentives for capital accumulation, investments and entrepreneurship. An economic sociology of capitalism needs to endogenize the state and market by examining the concrete interconnections between political and economic actors and the manner in which, actors compete and cooperate to shape the structure of property rights, influence the workings of financial institutions, and give form to incentives for investment and entrepreneurship through the tax laws, interest rates, and other regulatory mechanisms governing economic activity. (2005:xxxvii)

With these brief and suggestive examples we can begin to see the cultural construction of the modern economy and of capitalism. The special contribution of STS is that it can show how the new economic and political sciences of the seventeenth and eighteenth centuries, along with all the sciences that inform health, safety, and environmental "regulation," created the modern form of capitalism. Capitalism is thus, in important respects, itself a co-production of science and government (and of course economic actors as well). Further, it also is co-produced with the production of the capitalist state. From this perspective, rather than seeing the modern state as an actor, we can view it as the effect of actions, and thus as a condition of life, as a state of being. It is not something that stands outside of the economy and that then intervenes to regulate it. Yet it is the opposite view that gives us the most widespread notion of regulation, and with it a whole industry of "anti-regulation" think tanks, journals, conferences, and so forth. The economists have even written the history of regulation in terms of their economic precepts, so that it is something that emerges in the early twentieth century as a more "efficient" form of government intervention into business than was provided by litigation in the court system (though Robert Boyle referred to government "regulation" of trades in the 1670s). More broadly, "free 
trade" and "regulation" are discursive opposites that only make sense in relation to one another. The notion of the regulatory state is thus inseparable from the notion of an economy that exists prior to government. If, as I am suggesting, capitalism is constituted through specific cultural forms of science and governance, and manifest in equally specifiable state formations, then the very idea of the "regulatory state" becomes problematic. A more circumscribed idea of a regulatory "apparatus" of governance that operates in real-time is appropriate. The problem arises when the state is reduced to that apparatus, when agents and agencies of government are conflated with the state as a whole, and when the state is viewed as distinct from, in some naturalistic way, the economy. When I refer to the state as a whole I mean the state as a contested idea, a discourse and set of institutions, a set of practices variously organized into a system, and also as a material cultural formation in which natural forms, technologies, built environments, and people/bodies are incorporated (in the most literal sense of the term) and reconstituted.

Given how deeply institutionalized the idea and discourse of regulation has become, it can be no surprise that it is often employed with little critical reflection. It makes sense to analyze science and the state through the language of regulation, especially when research is finely attuned to actors and thus their own language. Environmentalists speak about successes and failures of regulation just as do consumer or workplace-safety advocates. This is fine as long as it is understood that the very boundaries between public and private are constituted interior to the state (Mitchel 2002); it does not get us to the more profound sense in which our very state of being, political, economic, and cultural, is co-produced by science and government. To fully understand this we need to relate the idea of regulation to the entire history of modern policy and police, their status as sciences, and their relations to other sciences.

I emphasize police because it points to the actual real-time interface of the regulatory apparatus with the mundane and everyday life of people and things. It is a productive form of police. Police is not only about coercion and repression in the conventional negative sense of these terms, but is positively productive of new social and natural orders and new states of being. Foucault documented the importance of policing and "regularization" in his lectures from 1975-76 (Foucault 2003), but his claim that the rise of liberal economics brought the dismantling of the police state or at least its reduction to a negative function is an error inherent to a poststructuralism that jettisons the analysis of ideology and conflates discourse with the world. Governmentality studies have subsequently focused on forms of liberal self-governance, failing to recognize that the police forms outlined in the eighteenth century were deployed with enormous reach in the nineteenth and twentieth, and that they continue to grow. The discourse of liberal governmentality has proved no match for the cultural logics of the processes of modern technoscientific formation, at the heart of which is police science.

The idea of the regulatory state is somewhat consistent with, but does not quite capture, the nature of the modern police state. Police, as the administration of life, has continuity across three centuries of modern state formation, despite its discourse as a form of government being muted my liberalism and now neoliberalism (Neocleous 2000). And to the extent that the regulatory apparatus meets the social body through the capillaries of enforcement, then regulation, as well as regularizing and constructing realities, is a form of coercion and repression. Indeed coercion and repression must be viewed not simply in the negative, in terms of negation, but as positive elements of constitutive government. "Regulation" is certainly often experienced at the point of enforcement as coercion. For instance, a meat processing plant owner in San Francisco felt so oppressed by the food safety police that he opened fire on them, killing three in the process. But more fundamentally, new realities are constituted through repression because it is the twin of permission in the constitutive state. Certain acts of pollution or conditions of ill health must be repressed through coercion, just as certain forms of economic activity and organization can be permitted. Of course, liberal histories of public health have entirely erased its roots in "medical police" (Carroll 2002); one cannot have the "good" of public health discursively tainted by the "bad" connotations of police. Market fundamentalists and neo-liberals, not surprisingly, recognize that regulation is a form of police, so they constantly assert that business can "police itself." Those who favor regulation, whether environmental, work place safety, product safety, public health and so on, tend not to see regulation as a form of police because "progressives" view the idea of a police state as antithetical to democracy. The language of police is muted despite the fact that advocates for health, safety and the environment reject the idea of voluntary compliance, favor compulsory enforcement, and 
champion prosecution of offenders. Both left and right, for different reasons, fail to recognize that modern states are police states, and that such police is constitutive of new forms of life. This is not to say that research on regulation does not address enforcement and prosecutions and the idea of "self policing." The contrary is clearly the case. But regulation is not articulated with a broader analysis of police and state formation, or of the nature of police states. The idiom of regulation provides discursive cover for progressives so that their gaze can be averted from police and from the theoretical problem of how it is possible for a police state to be a democratic and free state. Given progressives' concerted efforts to make regulation more enforceable, it might reasonably be expected that this issue be addressed. Market fundamentalist ideology, on the other hand, precludes an understanding of the role regulation and police play in the political and cultural constitution of the western variety of capitalism. Government is viewed only as a negation of true capitalism and pure natural markets.

Another problem with the regulatory state idea is that it implies a relatively fixed image of the state. I use the term "relatively" because, as Sheila Jasanoff has shown, this has begun to change as taken-for-granted categories have come in for critical reflection. She discusses two major developments in research on regulation that have exploded the notion that policy implementation, particularly in highly technical areas, follows a universalist trajectory driven my the inherent logic of science. The first shift, which was comparative, demonstrated how different "national styles" of regulation have been associated with different states (Jasanoff 2005). In this work, however, the nature of the state is not fundamentally questioned. States are like stages on which national styles are played out, and the close coupling of nation and state is assumed. The focus is on the process of regulatory government, its various steps from agenda setting to implementation. The regulatory state idea, rather than interrogated, is revealed in its diversity across different cultural contexts, an achievement welcome in the context of what had gone before, and extremely helpful in explaining variation in regulatory processes.

A second shift identified by Jasanoff has questioned the approach based on comparing "nation-states," emphasizing "the difficulty of taking entities such as 'science,' 'state,' or 'society' for granted as stable political units of analysis" (2005:19). This shift is informed by poststructuralist questions about the stability of analytic categories, and by growing concern with globalization and the undermining of boundaries between states. Here the very usefulness of the idea of "the state" fades into the background, and with it any attempt to theoretically interrogate what exactly we mean when we speak of the state. On the other hand, Jasanoff points out that STS has always been concerned with not only how categories are constructed and destabilized, but also how they sustain and gird social, natural, and political orders (2005). In this spirit she delicately plots a course between the unproblematic use of categories like "the state" in comparative work, and the tendency toward the dissolution of national differences in some poststructuralist and globalization research. She points out that to "understand how social entities such as 'the state' ... function in the world, one has to ask how diverse actors use and understand the concept, how it is articulated through formal and informal practices, where and by whom it is contested, and how it reasserts itself in the face of challenges to its integrity and meaning" (2005:19).

This observation and its related questions therefore apply to the very idea and idiom of the "regulatory state." Different actors will use and understand the concept of the state differently, and this will help explain their actions. This approach is fine if one wishes to understand the deployment of different meanings of the state articulated by actors with respect to some other more central concern of the research, such as the regulatory process and its relations to science and democracy. However, if one wishes to establish the actual ontology of the modern state, then restricting analysis of the state to actors' categories and understandings is insufficient. To access the actual character of the state, one needs to develop analytic categories, categories that are molded from actors' categories, but are not bound by the latter. Jasanoff acknowledges this, noting that we must "employ analytic categories different from those of decision makers operating within the policy process" (2005:23). It is not precisely her project in Designs on Nature to do this for the concept of "the state," or therefore for the concept of the regulatory state, but it is implicit in her analysis of the co-production of natural and social orders. The same approach is adopted here, though in a more macro-historical way, a way that is more centered on effects and outcomes than on the decision processes at the level of agonistic actors. The two foci are entirely compatible. A focus on state formation rather than the regulatory process, however, requires a critique of the actors' category of "regulatory state" and 
"regulation" and the deployment of analytic categories that move us beyond this now common sense idea. This critique is not to deny that the regulatory state idea captures an important characteristic of modern states (especially from the perspective of actors), but because it circumscribes a more comprehensive theory of modern states and state formation.

There is work now appearing that derives not from the focus on the regulatory process so much as the question of the role of the state in capitalist society, particularly in the context of the claims of neo-liberalism concerning the declining significance of the state, and in the analysis and formulation of policy. This work is more directly connected to the "French school of regulation" than to the historical sociology of state formation, but it comes closest to an analysis of the regulatory state as a state that is constitutive of the order of capitalism. David Levi-Faur, in particular, has advanced a view of the regulatory state idea in the constitutive sense argued for here, though he argues that "regulatory capitalism" better captures the relationship between state and economy since the 1980s. While noting some work that identifies a regulatory order in the nineteenth century, he sees regulatory capitalism as preceded first by welfare capitalism (1940s-1970s), and before that by laissez faire capitalism (1800s-1930s). Levi-Faur is worth quoting extensively here:

The new regulatory order is social, political, and economic. State, markets, and society are not distinct entities. Indeed, regulatory capitalism rests on an understanding of the relations between state and market along a condominium (Underhill 2003). The state is embedded in the economic and social order; any change in the state is expected to be reflected in the economy and the society, and vice versa. That much is reflected through the various dimensions of regulation. Thus, efficient markets do not exist outside the state and the society in which they operate, and efficient markets may require not only strong regulatory frameworks but also efficient ones (Polanyi 1944; Underhill 2003). Elsewhere I have argued that regulation-forcompetition may be a necessary condition for competition both in network industries and well beyond them (Levi-Faur 1998). Efficiency is often achieved through smart regulations that are a sine qua non for the efficient function of markets. At the same time, the legitimacy of capitalism rests on the ability of government to mitigate negative externalities through "social regulation" (or the regulation of risk). Regulation is both a constitutive [emphasis added] element of capitalism (as the framework that enables markets) and the tool that moderates and socializes it (the regulation of risk). From this point of view, the history of economic development is the history of regulation $(2005: 14)$.

The claim contained in this last sentence does not does not seem to gel with the claim that regulatory capitalism only emerges in the 1980s. And oddly enough, work in this tradition does not effectively link to work on "moral regulation," such as that by Alan Hunt (1999), and classically by Corrigan and Sayer (1985). Articulating ideas from Durkheim on moral order with Foucaultian ideas of individualizing/totalizing discourses, Corrigan and Sayer showed how the construction of moral individuals who culturally identified with the nation was central to the totalizing project of English state formation. In this instance regulation quite explicitly constitutes both subjects and the state (though Hunt critiques the emphasis on the state). In the context of these works it would appear that a constitutive view of the state does not so much go beyond the regulatory state idea, as flow directly from it. Again this is true as far as it goes, and it leads me to my final point and to the examples of Ireland and California: the language of regulation does not capture all the ways, indeed some of the most important ways, that modern states are co-produced by the agencies of science and government.

To fully capture the idea of the constitutive state I draw on Jasanoff's analytic of co-production (Jasanoff 2004). I suggest that the modern state is not so much an actor, as the effect of actions, in particular the actions of science and government. The modern state is crucially co-produced by science and government. It is co-produced in ideas, meaning, and discourse and in practices and organizations. Even the regulatory state idea is co-produced by science and government, and institutionalized through constant iteration. Analysts in turn adopt the actors' categories, for instance, that of "regulatory science," and thus become enrolled in the further construction of the regulatory state idea. Variously organized practices are then labeled in terms of regulation. Soon much of the apparatus of the state 
is understood in terms of regulation, and eventually "the state" becomes, essentially, a regulatory system.

Again, this is fine as far as it goes. It is the case that there now exists an institutionalized discourse of state regulation and a vast apparatus of government that can be called regulatory (though I would call it police), not to mention an ideologically organized opposition to regulation, and an established scholarly field of regulatory studies. But there are also other discourses and organizations of state, such as the military-fiscal, which emphasizes not the regulatory, but the coercive and revenue extracting dimensions of the state. There are discourses of state that emphasize its "autonomy" from specific socio-economic interests, which is the ground for explaining revolutions and state collapse. And governmentality studies emphasize the capillary nature of state power, questioning the view of power that sees it emanating from a central point. Without articulating the different dimensions of the state in a more comprehensive theory, the idea of the regulatory state appears partial.

More importantly from the perspective of STS, is that the idea of the regulatory state fails to capture the range of ways the state is co-produced by science and government. In addition, because the constitutive action of science and government remakes the materiality of the state through the land, bodies/people, and built environment, it is necessary to go beyond the idea that the state is only concretely manifest in the state-system. The modern state is also manifest in its bio-population, its techno-territory, and its infrastructural jurisdiction (see below). This also involves recognizing that states are conditions, places, and orders rather than actors. Of course, sovereign governments act in the name of states, as do the agents and agencies of the state-system, but this simply indicates the need for much greater analytic clarity in the terminology we use to talk about the state.

\section{SCIENCE, GOVERNMENT, AND THE CO- PRODUCTION OF THE MODERN STATE}

I turn now to the broader ways that science and government co-produce the modern state, making reference to the cases of Ireland and California. Ireland is an ideal case for viewing the process of modern state formation through the co-production of science and government. The country (as with many colonies) was treated as a laboratory for experimental statecraft by the English, first and notably by William Petty in the mid-seventeenth century. A Baconian discourse emerged at that time that trumpeted the aggrandizement of the state and the economic development that would follow from the application of the new experimental science to objects of government. The new science was inherently interventionist, marrying natural philosophy to mathematics and engineering. In this context Petty conceived of what he called "political anatomy", "political arithmetic", "political medicine", and Marx later credited him with being a founder of "political economy." Political anatomy involved the dissection of the state, distinguishing all its elements and the connections between these elements, which were both human and non-human (for instance, he included the character of the soil and also the weather in his political anatomy). Political anatomy was in effect a probe and a scope upon the body of the state. In this sense it articulated and could be integrated with the scoping activity of his cartographic survey. But this scoping activity did not produce a mere description of the state; it began a process of re-conceptualizing and reordering the state. All manner of economic data was collected, including the quality of land, the location of ports, the extent of forests, the potential of fisheries, the navigability of rivers, and the quality of labor. Once scoped out the country was quantified. Political arithmetic transduced everything into number so that it could be calculated. The entire country was "valued," and given a price. A census was conducted, and mortality rates and causes of death recorded. All of this was aimed at re-engineering the state to make it more powerful. As Petty put it,

pollicy or the Art of Government seems to bee the most considerable faculty of a Man. For how wonderfull is it, that the spiritt of one Generall of an Army should influence, consimulate \& semitrize the Minde, manner and Motions of 40000 men, or rather that one Monarch should consenture and draw together the Mentall \& Corporal Facultyes of 10 Millions of Men (1927:28).

Petty's political medicine was central to this ambition. Though the idioms of population and public health had not yet emerged, Petty posited a healthy people as key to a powerful wealthy state. Here science and government united to intervene in the affairs of physicians as a matter of reason of state:

Now suppose that in the King's Dominions there be 9 millions of People, of which 
360,000 dye every year, and from whom 440,000 are borne. And suppose that by the advancement of the art of Medicine, a quarter part more may be borne and a quarter part fewer dye. Then the King will gain and save 200,000 subjects per annum, which valued at 20 [pounds] per head, the lowest price of slaves, will make 4 million per annum benefit to the Commonwealth. ... Wherefore it is not the Interest of the State to leave Phisitians and Patients (as now) to their own shifts (1927:176).

Despite Petty's many neologisms, he did not coin the term "political economy," but as Marx recognized, it is implicit throughout his political anatomy, arithmetic, and medicine (1974:85 note 1). Though many of Petty's grander schemes never came to pass in his lifetime, most where eventually adopted. For instance, his idea for a registry of lands in Ireland would not be achieved till the mid-nineteenth century. His broader vision of re-engineering the state through science and government endured. Over the following two centuries we see land, bodies/people, and built environment become boundary objects (Star and Griesemer 1989) for scientifically informed government interventions and transformations (Carroll 2006). With respect to land, government and science come together through projects in cartography, geology, natural history, fisheries and forestry management, hydraulics and drainage, and experimental agriculture, the latter drawing on sciences such as chemistry and natural history (and later biology and biochemistry). Of tremendous importance in the Irish case is the Ordnance Survey, completed in 1846. This survey was not simply the most accurate cartography ever produced at the time, it was an ethnography of the people, a survey of their political and "social [moral] economy," a survey of the ancient and modern topology of the island, and a lexicographic survey that facilitated the translation of the country into the English language. And it was integrated with the geological survey, the census, and the new land valuation. In the case of Ireland the landmass claimed as territory was transformed into a techno-territory out of which the state was engineered. To this day all construction plans must be shown on ordnance survey maps.

With respect to the built environment we find model building designs, sanitary engineering, ventilation systems, structural mechanics, and road construction. Road construction should not be underestimated either in terms of the science of such or its importance to state formation. The Royal Dublin Society (modeled on the Royal Society of London), regularly issued instructions in the eighteenth century on techniques and materials for road construction. The roads in turn became the arteries through which government and law penetrated deep into the countryside. Practically every material dimension of the built environment is subject to the "building code," not simply the plumbing of sewers and water supply. The integrity of walls, chimneys, electrical systems, even the space between steps on a stair is subject to the code. These coproductions of technoscience and government are not well captured in the language of the regulatory state. Indeed the material culture of the built environment is transformed into a jurisdictional infrastructure that is itself, in its very materiality, an agent of government and order.

Finally, in the case of bodies/people there is public health and safety, toxicology, sanitary science, and disciplinary pedagogy. Though the activities related to public health and safety could be viewed in terms of regulation, they are better captured by the eighteenth and nineteenth centuries discourse of "medical police" (Carroll 2002). As discussed above, regulation is centrally a matter of policing, but the idiom of regulation distracts us from the more troubling idea of the police state. In addition, sanitary engineering is not well captured by the language of regulation, nor is road construction or cartography. The point again is that the co-productive actions of science and government are transforming land, people and built environment. New realities are constituted as land, people, and built environment are incorporated into the state. Indeed the state itself is transformed and reconstituted, as is the economy and the political culture. The metering and scoping of society gives rise to a new data state and scopic regime. Geology, soil science, natural history, cartography, and censuses even shape the valuation of the country and design of taxation schemes (taxation design also preoccupied Petty). Indeed, capitalism as we know it would be unthinkable without the coproductions of science and government. None of this can be captured effectively by the notion of the regulatory state. It is not only about regulating, it is about scoping, metering, graphing, and engineering.

The constitutive state co-produced by science and governance is even more dramatically demonstrated in the case of California, and the material re-engineering of that state in the service of water storage/conveyance and flood control. Though Ireland was also transformed 
through government built arterial drainage system, which involved altering soil and surface conditions, surrounding fields with ditches, draining the ditches into streams, and linking the streams with re-engineered rivers, the vast engineering that transformed California is stunning. And as in Ireland, the engineering projects brought government and a range of sciences, such as geology, cartography, hydrography, and biology, into concerted action. Unlike Ireland, however, there was no strong central government in California when it was founded as a U.S. state in 1850 , and the role of the federal government was minimum. The role of the federal government should not, however, be thought of as entirely insignificant. Throughout the nineteenth century the federal government funded a surprisingly large number of projects and surveys concerned with cartography, natural history, ethnography, etc., and the subsequent knowledge these produced was central to the colonization of the west (Frankel 2006). Particularly important in the case of California was the federal government's survey for the transcontinental railway, the strong federal financial backing for its construction, and the decisions to have it terminate in the west in the city of Sacramento, the (eventual) capitol of the state. The American case highlights the fact that modern state formation cannot be overly tied to a strong centralized power. All scales of practice and organization where government and science join together, whether national, state/provincial, county, city, and district (or cantons, departments, etc.) need to be viewed as part of the process of state formation. This is particularly the case in California, where the water conveyance and flood control infrastructure stitches together, if somewhat chaotically, different jurisdictional domains. In the U.S. the commerce clause of the constitution, which permits federal government of interstate activities, is widely recognized as the primary means through which the federal government's power has been extended, and until the early twentieth century federal action was largely confined to inland navigation and trade. However with the creation of the Reclamation Service within the United States Geological Survey in 1902 (later becoming the Bureau of Reclamation within the Interior Department), and the passing of the Flood Control Act of 1917, federal governing power was extended through their infrastructural jurisdiction over key parts of California's water system (Carroll 2012; O'Neill 2006). The formation of California as a state with close to forty million people and one of the largest economies in the world, in the space of just one hundred and fifty years, is the story of a landmass being transformed into a highly governed state in which "nature" is mobilized through science in the service of development.

When gold was discovered east of Sacramento in 1848 the non-native population of the state was only about 10,000 . Two years later, when the state entered the union, the settler population surged to 100,000 . In 1849 , the City of Sacramento was formally founded, quickly becoming a hub of the gold rush traffic. Sacramento sat on the northern edge of a delta region located within the triangle formed by the meeting of the Sacramento River from the north, the San Joaquin River from the south, and San Francisco Bay to the west. The delta was at this time annually flooded by the rivers that drained into it, and the sediment they deposited was regularly scoured-out by the tidal currents of the Pacific, currents that could extend a hundred miles inland. Floods regularly inundated the southern San Joaquin Valley to the south, and Sacramento Valley in the north. The City of Sacramento was devastated by flood within months of its founding. A decision was made to build a levee around the town, and for the first time in the state an engineering survey for doing so was launched. As agricultural settlement rapidly followed the gold rush, a frantic era of levee building began, on the rivers and within the delta itself. By the 1860s, levee and reclamation districts were being created, and by the end of the century hundreds of miles of levee had been constructed and thousands of acres of land reclaimed for agriculture. The federal government "gifted" land to the state government, which handed it out to individuals for next to nothing as long as the applicant committed to draining, "improving," and thus "reclaiming" it. As uncoordinated individuals set about reclamation it soon became clear that one man's levee led to another's land flooding (Kelley 1998). By the 1870 s settlers were actually attacking and destroying each other's reclamation earthworks, as each attempt to steer the water off one plot led to the flooding of another. The problem became especially acute along the banks of the Sacramento River, where owners on either side raced to build levees that caused the river to flood on the other side or further downstream. Further chaos resulted from government permitting unrestricted hydraulic mining in the gold-rich foothills. Whole hillsides were wiped away and millions of tons of "debris" washed down the rivers and into the delta, flooding agricultural lands and clogging shipping channels.

It is important to note in this context, that just as silences can be as important as articulations in 
discourse, so permissive government can constitute a state of affairs just as surely as interventionist government. Much of the chaos resulting from laissez faire government continued through to the turn of the century, but state government began to act as early as 1862, when legislation was passed that envisioned a state governed policy of land reclamation. A board of Swampland Commissioners was created, and it immediately turned to technoscience for help in coordinating levee building with "natural" drainage patterns. Reclamation districts, the first administrative districts in the state, were created. Their governing powers were isomorphic with those of municipalities, and their charge was to govern levee construction. Levee building around private properties was prohibited, and instead levees were to be built for the benefit of the entire reclamation district. All plans were to be drawn up by engineers appointed by the commission. Property owners soon manipulated the system even to the point of having an entire governing district be coterminous with a single piece of private property. Five years later the commission was abolished and the district powers delegated by the state government to the county governments. Every county surveyor became an ex-officio engineer of reclamation, and all plans were to be reviewed to ensure they articulated with a larger regional system of levees. County governorship brought its own problems, as counties split between farming counties and mining counties. As well as depositing debris in the rivers upstream from the farmers, miners redirected stream flows and sometimes exhausted streams completely. Unlike in Ireland, where a strong centralized government throughout the nineteenth century pushed forward reclamation, drainage, improvement, flood mitigation, cartography and so on, California became a confused mix of governing agencies, legal judgments, and ideological swings, inching toward state government control of water while never quite getting there (which is still to some extent true today).

All attempts to control the Sacramento River failed. In 1907, after one of the most devastating floods to date (each advance of development led to greater losses from floods), a flood bypass plan was adopted, resulting in the engineering of the Sutter and Yolo county bypasses. The story of the decision to engineer a bypass system is too complicated to go into here, and in any case I am less concerned in this paper to explain that decision than to document how state and federal governments increasingly intervened over matters of water conveyance and flood control, and how, in conjunction with science, government began to engineer the modern state of California. Though far from eliminating floods, they were significantly mitigated, paving the way for further development and population growth. Between 1910 and 1920 the agricultural boom in the Central Valley took off, the number of farms growing by about $70 \%$, and the population growing by about $50 \%$. The state of California was being reconstituted as an agricultural empire through the combined action of government and science. Development demanded power and water supplies, and so began the era of big dams such as that in the Hetch Hetchy Valley, which still serves the city of San Francisco. The most important event in the history of the engineering of California, however, is the launch of the Central Valley Project (CVP) in the 1930s, and subsequently the State Water Project (SWP) in the 1950s.

The CVP begins the process of materially engineering the delta region into the state as whole, as it became the hub for delivering water from the wetter north to the dryer south. Direct federal involvement in California water issues got under way in earnest with creation of the California Debris Commission (CDC) in 1892 (composed of technoscientists from the United States Army Corps of Engineers), the Reclamation Service in 1902, and the 1917 Flood Control Act. But the CVP, commenced in 1935, would place the federal government at the center of what would become the engineered backbone on the entire California state formation. It began in 1930 as a State Water Plan (preceded by other plans such as the "Marshall Plan" a decade earlier), but as the state government could not sell the bonds to finance it due to the Great Depression, it was taken over by the federal government. It was in the context of the CVP that major headwater damming began, resulting in huge dams like the Shasta, which was completed in 1945, and the Folsom, built in the 1950s. In 1957 a new State Water Project (SWP) was launched, and the state government completed the project with the construction of Oroville Dam and the California Aqueduct. Practically every major river in the state is now dammed, bringing into existence an entirely new social and natural order in the state. Giant pumping stations on the western side of the delta deliver water almost 450 miles to Central and Southern California. The entire delivery system comprised about 650 miles of canals and pipelines, and a complex system of regulating reservoirs. Today there is a range of science/federal government organizations that maintain 
parts of the water control and conveyance system that holds the state as now constituted together, for instance, the United States Army Corps of Engineers, the United States Geological Survey, the Bureau of Reclamation, and the National Oceanic and Atmospheric Administration. Technoscientists are also at work in a range of state and regional governing organizations, for instance, the California Department of Water Resources, the Delta Stewardship Council, the Department of Fish and Game, and the Sacramento Area Flood Control Agency. And the governing apparatus also includes numerous other regional, municipal, and district agencies. This complex of governance is dis/articulated in different ways and can by no means be understood as a single centralized system.

Though the water system is variously lauded as a fabulous engineering achievement, as an engine of environmental destruction, or locus of government corruption, there is no question that the contemporary state of California is built into and out of its material infrastructure, an infrastructure co-produced by science and government. The system stitches governing agencies together at the federal, state, regional, local, and special district scales. This makes the government of the state complex and convoluted, but constitutive of a new order nonetheless. Deserts and semi-arid environments have been made farmland. Indeed the entire central valley landscape has been transformed. The water flows on every major river are constantly monitored, metered, and managed. Even water temperatures are manipulated for fisheries management. A state population of almost forty million people is supplied with water - at least part of the supply for 23 people million flowing from north to south through the delta and the aqueducts. This population sustains an economy that ranks in the top ten of "nation-state" economies in the world, an economy that provides the revenue that feeds the education and health systems, as well as an extensive regulatory and policing apparatus. Finally, a whole new political culture has been created, at the heart of which today is environmentalism.

The most profound new reality and new state of being co-produced by science and government in the case of California is the complete engineering of nature and society together through material technologies. Relatedly, the water system is a stunning instance of infrastructural jurisdiction, of the engineering of a material backbone of state power. The security of state, the vitality of the economy, and the sustainability of life itself, are now thoroughly bound together through the water conveyance and flood control infrastructure. If these systems were to fail in the heart of the California system, the delta region, the result could make New Orleans after Hurricane Katrina look like a picnic.

\section{CONCLUSION}

Though this discussion of Ireland and California is very brief and broad stroked, it shows how the regulatory state idea evokes an overly circumscribed view of science/state relations. The regulatory apparatus is just one, admittedly important, element of the modern state system. And as noted above, the regulatory apparatus can be seen as part of the constitutive state in that regulation is itself a science/government system that produces a particular form of social order. Once again a major issue is the terminology we use when talking about the state. The state is not simply a system, it is also a material formation, a condition of life, and a condition of possibility for capitalist economic development. Modern capitalist economies are constituted within modern capitalist states. They are not realities that exist independently or in advance of the state, realities that are then, post hoc, regulated. States are places that are ordered in a particular way, sometimes in a capitalist way and sometimes not. The solution to the riddle that has the state being everywhere and yet nonstate actors being everywhere too, is that the very distinction between state actors and non-state actors is constituted within states. As such it is more accurate to speak of governments rather than states acting. This is not to suggest, as many in the tradition of governmentality studies do, that reference to sovereign states should be displaced from analysis. It is less a case of cutting off the king's head in political theory, as it is of locating sovereign government action within a field of action. Then when we view the state we see not one head, but many actors acting in the name of one head. The state remains of central importance, but not in the sense of a singularized and centralized actor from whence all power emanates. The state remains central because it constitutes the order in which all action in the modern context occurs. Of course the actor-state idea is deeply institutionalized and is real to that extent, but at the level of practice and organization the state-system appears much more complex than the image of a single actor can capture. In addition, as institutions are fundamentally meaning structures that enable and constrain action, they can hardly be conceived as actors themselves. 
While part of what is at issue here is analytic terminology, it is not merely a matter of semantics. To say the "state government" acts is not equivalent to saying that the state itself acts. The idiom of the actorstate, whether understood in terms of regulation or otherwise, limits our ability to see the state as a material formation built into and out of bodies, built environment, and land. And while it need not necessarily do so, the regulatory state idea easily implies that the almighty market exists prior to the state. This ontological distinction then serves as the basis for the anti-regulatory movement of market fundamentalists. However, some work that operates within the regulatory idiom, particularly that of Sheila Jasanoff, reveals regulation as constitutive of new natural, social, and political orders. So when I suggest going beyond the regulatory state idea, I am not claiming that any talk of regulation is problematic. Rather I am suggesting that we need much greater emphasis on how the regulatory, in addition to the scopic, the metrologizing, and the engineering dimensions (Carroll 2006; Mukerji 1994, 1997) of state formation reveal the powers of knowledge and government as constitutive of the modern capitalist state.

\section{REFERENCES}

Biernacki, R. (1995). The fabrication of labor: Germany and Britain, 1640-1914. Berkeley: The University of California Press.

Boyle, R. (1663). Some considerations touching the usefulness of experimental natural philosophy. The second tome. In: Boyle, R: The Works. Vol. 3. Hildesheim: Georg Olms Verlagsbuchhandlung.

Carroll, P. (2002). Medical police and the history of public health. Medical history. 46, 461-94.

Carroll, P. (2006). Science, culture, and modern state formation. Berkeley: The University of California Press. http://dx.doi.org/10.1525/california/9780520247536.001.0001

Carroll, P. (2012). Water and technoscientific state formation in California. Social studies of science. 42(4), 489-516. http://dx.doi.org/10.1177/0306312712437977

Callon, M, Millo, Y, Muniesa, F. Eds. 2007. Market devices. Malden MA: Blackwell Publishing.

Carruthers, B. (2005). Historical sociology and the economy: Actors, networks, and context. In: Adams, J, Clemens, E, and Orloff, A. Eds. Remaking modernity: politics, history, and sociology. Chapel Hill, NC: Duke University Press.

Corrigan, P. and Sayer, D (1985). The great arch: English state formation as cultural revolution. Oxford: Blackwell Publishers.

Curtis, B. (2001). The politics of population: State formation, statistics, and the census of Canada, 1840-1875. Toronto: University of Toronto Press.

Curtis, B. (2002). Foucault on governmentality: The impossible discovery. Canadian journal of sociology. 27(4), 397-412. http://dx.doi.org/10.2307/3341588

Epstein, S. (1995). The construction of lay expertise: Aids activism and the forging of credibility in clinical trials. Science, technology, and human values. 20(4), 408-437. http://dx.doi.org/10.1177/016224399502000402
Foucault, M. (2003). Society must be defended. New York: Picador.

Foucault, M. (2007). Security, territory, population: Lectures at the Collège de France, 1977-78. Basingstoke: Palgrave Macmillan. http://dx.doi.org/10.1057/9780230245075

Frankel, O. (2006). States of inquiry: Social investigations and print culture in nineteenth-century Britain and the United States. Baltimore: Johns Hopkins University Press.

Gieryn, T. (1983). Boundary work and the demarcation of science from non-science: Strains and interests in professional ideologies of scientists. American sociological review. 48, 781-95. http://dx.doi.org/10.2307/2095325

Hunt, A. (1999). Governing morals: A social history of moral regulation. New York: Cambridge University Press.

Jasanoff, S. (1987). Contested boundaries in policy-relevant science. Social studies of science. 17, 195-230. http://dx.doi.org/10.1177/030631287017002001

Jasanoff, S. (1990). The fifth branch: Science advisers as policymakers. Cambridge, MA: Harvard University Press.

Jasanoff, S. (1995). Science at the bar: Law, science, and technology in America. Cambridge, MA: Harvard University Press.

Jasanoff, S. (2004). States of knowledge: The co-production of science and social order. New York: Routledge. http://dx.doi.org/10.4324/9780203413845

Jessop, B. (2002). The future of the capitalist state. Cambridge: Polity Press.

Kelley, R. (1998). Battling the inland sea: Floods, public policy, and the Sacramento Valley. Berkeley: The University of California Press.

Kelman, S. (1981). Regulating America, regulating Sweden: A comparative study of occupational safety and health policy. Cambridge: The MIT Press.

Knorr-Cetina, K, Preda, A. Eds. (2006). The sociology of financial markets. Oxford: Oxford University Press.

Kuhn, T. (1962). The structure of scientific revolutions. Chicago: The University of Chicago Press.

Latour, B. (2004). Why has critique run out of steam?: From matters of fact to matters of concern. Critical inquiry. 30, 225-248. http://dx.doi.org/10.1086/421123

Levi-Faur, D. (2005). The global diffusion of regulatory capitalism. The annals of the American academy of political and social science. March, 12-32. http://dx.doi.org/10.1177/0002716204272371

MacKenzie, D, Muniesa, F, Siu, L. (2007). Do economists make markets: On the performativity of economics. Princeton: Princeton University Press. http://dx.doi.org/10.7551/mitpress/9780262134606.001.0001

MacKenzie, D. (2006). An engine, not a camera: How financial models shape markets. Boston: The MIT Press.

Marx, K. (1974). Capital: A critical analysis of capitalist production, Vol. 1. London: Lawrence \& Wishart.

Marx, K, Engels, F. (1998) The communist manifesto. Signet Classics. New York: Penguin.

Mitchell, T. (2002). Rule of experts: Egypt, techno-politics, modernity. Berkeley: The University of California Press.

Mukerji, C. (1994). The Political Mobilization of Nature in Seventeenth Century French Formal Gardens. Theory and society. 23(5), 651-677. http://dx.doi.org/10.1007/BF00992906

Mukerji, C. (1997). Territorial ambitions and the gardens of Versailles. Cambridge: Cambridge University Press.

Nee, V, Swedberg, R. (2005). The economic sociology of capitalism. Princeton: Princeton University Press. 
Neocleous, M. (2000). The fabrication of social order: A critical theory of police power. London: Pluto Press.

O'Neill, K. (2006). Rivers by design: State power and the origins of U.S. flood control. Durham, NC: Duke University Press. http://dx.doi.org/10.1215/9780822387862

Petty, W. (1927). The Petty papers: Some unpublished writings of Sir William Petty. Vol. 2. London: Constable.

Poovey, M. (1998). A history of the modern fact: Problems of knowledge in the sciences of wealth and society. Chicago: The University of Chicago Press. http://dx.doi.org/10.7208/chicago/9780226675183.001.0001

Petty, W. (1851 [c.1659]). A briefe accompt of the most material passages relatinge to the survey managed by Doctor Petty in Ireland, anno 1655 and 1656. In: Larcom, T. Ed. Petty, W. The history of the survey of Ireland, commonly called the down survey. Dublin: Irish Archaeological Society.

Petty, W. (1927 [1676]). Anatomy lecture. In: The Petty papers: Some unpublished writings of Sir William Petty. Vol. 2. London: Constable.
Poulantzas, N. (1969). The problem of the capitalist state. New left review $1(58), 67-78$.

Shadwell, T. (1676). The virtuoso, a comedy acted at the Duke's Theatre. London: Henry Harringman.

Skocpol, T. (1979). States and social revolutions: A comparative analysis of France, Russia, and China. New York: Cambridge University Press. http://dx.doi.org/10.1017/cbo9780511815805

Star, L, Griesemer, J. (1989). Institutional ecology, translations and boundary objects: Amateurs and professionals in Berkeley's Museum of Vertebrate Zoology, 1907-39. Social studies of science 19(3), 387-420. http://dx.doi.org/10.1177/030631289019003001

Tilly, C. (1999). Epilogue, now where?. In: Steinmetz, G. Ed State/culture: State formation after the cultural turn. Ithaca, NY: Cornell University Press.

Tilly, C. (1992). Coercion, capital, and European states, AD 9901992. Malden, MA: Blackwell Publishers.

\section{(C) 2015 Patrick Carroll; Licensee Lifescience Global.}

This is an open access article licensed under the terms of the Creative Commons Attribution Non-Commercial License (http://creativecommons.org/licenses/by-nc/3.0/) which permits unrestricted, non-commercial use, distribution and reproduction in any medium, provided the work is properly cited. 